\title{
Pengaruh Model Circuit Learning Berbantuan Media Gambar Terhadap Kompetensi Pengetahuan PPKn Siswa Kelas V SD
}

\author{
Ni Putu Sinta Fitriani1 ${ }^{1}$ I.G.A.Agung Sri Asri², I Gusti Agung Oka Negara ${ }^{3}$ \\ 1 Jurusan Pendidikan Dasar, Universitas Pendidikan Ganesha, Singaraja, Indonesia \\ e-mail: : putu.sinta.fitriani@undiksha.ac.id ${ }^{1}$, igaagungsri.asri@undiksha.ac.id² ${ }^{2}$, igustiagungoka.negara@undiksha.ac.id ${ }^{3}$
}

\section{Abstrak}

Penelitian ini bertujuan untuk mengetahui pengaruh model Circuit Learning berbantuan media gambar terhadap kompetensi pengetahuan PPKn siswa kelas V SD Gugus VI Kecamatan Mengwi tahun ajaran 2018/2019. Penelitian ini merupakan jenis penelitian eksperimen semu dengan rancangan nonequivalent control group design. Populasi penelitian ini seluruh kelas V SD di Gugus VI Kecamatan Mengwi tahun ajaran 2018/2019 yang berjumlah 210 siswa. Sampel ditentukan dengan teknik random sampling. Sampel dalam penelitian ini adalah kelas V SD No. 4 Kapal sebanyak 31 siswa sebagai kelompok eksperimen dan kelas V SD No. 1 Kapal sebanyak 39 siswa sebagai kelompok kontrol. Pengumpulan data dilakukan menggunakan metode tes dengan bentuk tes objektif pilihan ganda biasa. Data yang diperoleh dianalisis menggunakan uji-t. Hasil analisis data diperoleh $t_{\text {hitung }}=3,474$ sedangkan pada taraf signifikansi $5 \%$ dan $\mathrm{dk}=68$ diperoleh nilai $\mathrm{t}_{\text {tabel }}=2,000$ sehingga $t_{\text {hitung }}>t_{\text {tabel }}(3,474>2,000)$. Berdasarkan kriteria pengujian, maka $\mathrm{H}_{0}$ yang berbunyi tidak terdapat perbedaan yang signifikan kompetensi pengetahuan PPKn antara kelompok siswa yang dibelajarkan dengan model Circuit Learning berbantuan media gambar dengan kelompok siswa yang dibelajarkan dengan model pembelajaran konvensional pada kelas V SD Gugus VI Kecamatan Mengwi tahun ajaran 2018/2019 ditolak dan Ha diterima. Nilai rata-rata gain skor ternormalisasi kompetensi pengetahuan PPKn kelompok eksperimen adalah $\bar{X}=0,666$, sedangkan kelompok kontrol adalah $\bar{X}=0,534$. Berdasarkan hasil penelitian dapat disimpulkan terdapat pengaruh model Circuit Learning berbantuan media gambar terhadap kompetensi pengetahuan PPKn siswa kelas V SD Gugus VI Kecamatan Mengwi tahun ajaran 2018/2019. Disarankan kepada peneliti lain dapat digunakan sebagai referensi untuk melaksanakan penelitian selanjutnya.
\end{abstract}

\section{Pendahuluan}

Pendidikan harus dibangun dan dikembangkan agar mampu meningkatkan kualitas sumber daya manusia di Indonesia. Pendidikan mempunyai peranan penting dalam menjamin kemajuan suatu bangsa. Menurut Hamalik (2017:2) pendidikan adalah suatu proses dalam rangka mempengaruhi peserta didik supaya mampu menyesuaikan diri sebaik mungkin dengan lingkungannya, dan dengan demikian akan menimbulkan perubahan dalam dirinya yang memungkinkannya untuk berfungsi secara adekwat dalam kehidupan masyarakat. Pendidikan 
yang baik akan mampu menghasilkan SDM berkualitas, mampu bersaing, memiliki budi pekerti luhur, dan dapat mengabdikan diri pada negara.

Kurikulum memegang peranan penting dalam proses pembelajaran. Kurikulum yang diterapkan akan menjadi pedoman dalam pelaksaaan pembelajaran. Menurut Undang-undang Nomor 20 Tahun 2003 tentang Sistem Pendidikan Nasional disebutkan bahwa Kurikulum adalah seperangkat rencana dan pengaturan mengenai tujuan, isi, dan bahan pelajaran serta cara yang digunakan sebagai pedoman penyelenggaraan kegiatan pembelajaran untuk mencapai tujuan pendidikan tertentu. Peranan Kurikulum di sekolah sangatlah strategis dan menentukan bagi tercapainya tujuan pendidikan. Untuk mencapai tujuan pendidikan tersebut berbagai upaya telah dilakukan pemerintah salah satunya dengan melakukan pengembangan terhadap Kurikulum pendidikan di Indonesia. Saat ini, pelaksanaan pendidikan di Indonesia menggunakan Kurikulum 2013 atau K13. Kurikulum ini memiliki 4 aspek yang materi-materinya terintegrasi dan terpadu dalam suatu tema yang disebut tematik terpadu. Menurut Permendikbud Nomor 24 Tahun 2016 disebutkan pelaksanaan pembelajaran Kurikulum 2013 pada Sekolah Dasar/Madrasah Ibtidaiyah (SD/MI) dilakukan dengan pendekatan pembelajaran tematik terpadu, kecuali untuk mata pelajaran Matematika, dan Pendidikan Jasmani Olahraga dan Kesehatan (PJOK) sebagai mata pelajaran yang berdiri sendiri untuk kelas IV, V, dan VI.

Pembelajaran ini menggunakan pendekatan saintifik atau pendekatan berbasis proses keilmuan dengan pembelajaran tematik integratif yang sudah diterapkan di SD. Pembelajaran tematik integratif yaitu mengaitkan beberapa kompetensi dasar dari mata pelajaran yang dipadukan kedalam sebuah tema. Beberapa mata pelajaran dipadukan dalam pendekatan saintifik seperti Bahasa Indonesia, PPKn, Matematika, IPA, IPS, Penjaskes, dan SBdP yang dipadukan sedemikian rupa sehingga siswa tidak menyadari sedang mempelajari mata pelajaran tertentu. Dari berbagai mata pelajaran tersebut, PPKn merupakan salah satu mata pelajaran yang sering muncul dalam kegiatan pembelajaran untuk mengembangkan nilai, sikap dan kepribadian yang sesuai dengan Pancasila, UUD 1945, cinta tanah air, dan berwawasan kebangsaan. Menurut Susanto (2013:234) PPKn bertujuan untuk menjadikan warga negara yang baik, yaitu warga negara yang tahu, mau, dan sadar akan hak dan kewajiban. Mata pelajaran PPKn tidak hanya menekankan pada aspek kognitif saja tetapi mencakup semua aspek yang bertujuan untuk mengembangkan potensi individu agar menjadi warga negara yang aktif dan partisipatif.

Berdasarkan hasil observasi di SD Gugus VI Kecamatan Mengwi pada tanggal 15 Januari 2019, diperoleh informasi bahwa guru masih kesulitan dalam menerapkan Kurikulum 2013. Guru masih terfokus pada perubahan Kurikulum dan belum terbiasa menerapkan strategi belajar seperti penerapan model dan penggunaan media dalam pembelajaran, sehingga pembelajaran menjadi kurang bervariasi dan memotivasi siswa. Minat beberapa siswa untuk memperhatikan pembelajaran yang sedang berlangsung masih kurang karena sedikitnya penggunaan variasi model dan media selama proses pembelajaran dan dapat mempengaruhi kontribusi siswa dalam proses pembelajaran. Belum optimalnya nilai penguasaan kompetensi pengetahuan siswa terhadap materi mata pelajaran PPKn disebabkan karena ada suatu pemahaman yang salah dengan menyatakan PPKn sebagai pelajaran yang cenderung hafalan. Permasalahan tersebut mengakibatkan penyerapan materi pelajaran oleh siswa masih belum optimal sehingga berimbas pada kompetensi pengetahuan, terutama kompetensi pengetahuan PPKn. Dari data salah satu SD di Gugus VI Kecamatan Mengwi, rata-rata pencapaian kompetensi pengetahuan PPKn siswa kelas V hanya 76,32 dan rata-rata tersebut termasuk rendah dibandingkan dengan mata pelajaran yang lainnya.

Berdasarkan permasalahan yang dikemukakan untuk meningkatkan hasil belajar peserta didik, maka upaya yang peneliti lakukan dalam perbaikan memakai suatu model pembelajaran yang terdapat metode atau strategi baru dan menarik bagi siswa. Salah satunya model pembelajaran kooperatif. model ini identik dengan adanya suatu interaksi antar siswa dalam mengomunikasikan suatu ide atau gagasan. Ada banyak model pembelajaran yang dapat diberikan kepada peserta didik saat proses pembelajaran berlangsung, salah satunya model Circuit Learning merupakan strategi pembelajaran yang memaksimalkan pemberdayaan pikiran dan perasaan dengan pola penambahan (adding) dan pengulangan (repetition). Di dalam pelaksanaan pembelajarannya, siswa akan menjawab pertanyaan yang diberikan tentang topik 
yang dibahas, penyajian peta konsep, penjelasan mengenai peta konsep, pembagian ke dalam beberapa kelompok, pengisian lembar kerja siswa disertai dengan peta konsep, penjelasan tentang cara pengisian, pelaksanaan presentasi kelompok, dan pemberian reward atau pujian.

Model Circuit Learning dapat menambah kreatifitas siswa dan mengaktifkan siswa karena membuat pengetahuan siswa yang didapat dalam pembelajaran dialami sendiri oleh siswa sehingga menjadi bermakna dan sulit dilupakan. Sejalan dengan pendapat tersebut, Huda (2014:311) menyatakan model Circuit Learning merupakan strategi pembelajaran yang memaksimalkan pemberdayaan pikiran dan perasaan dengan pola penambahan (adding) dan pengulangan (repetition). "Model Circuit Learning adalah memaksimalkan dan mengupayakan pemberdayaan pikiran dan perasaan dengan pola bertambah dan mengulang" (Shoimin, 2014:33). Pola belajar menambah dan mengulang setiap hari ini akan meningkatkan pemahaman konsep siswa dan daya ingat siswa karena konsep pelajaran yang mereka dapatkan sebelumnya ditambah dan diulang dengan konsep pelajaran yang baru. Disebut model belajar memutar karena siswa benar-benar menempuh informasi dalam pola yang sama setiap hari. Model Circuit Learning bermanfaat untuk memaksimalkan pemberdayaan pikiran dan perasaan dengan pola bertambah dan mengulang (Siswanto, 2016:58). Strategi ini biasanya dimulai dari tanya jawab tentang topik yang dipelajari, penyajian peta konsep, penjelasan mengenai peta konsep, pembagian ke dalam beberapa kelompok, pengisian lembar kerja siswa disertai dengan peta konsep, penjelasan tentang tata cara pengisian, pelaksanaan presentasi kelompok, dan pemberian reward atau pujian. Cara pembelajaran seperti ini akan lebih cepat dipahami siswa. Kelebihan model Circuit Learning adalah kreativitas siswa dalam merangkai kata dengan bahasa sendiri lebih terasah dan konsentrasi yang terjadi membuat siswa fokus dalam belajar (Siswanto, 2016:59). Model ini cocok diterapkan pada kelas $\mathrm{V}$ yang pada dasarnya siswa di kelas $\mathrm{V}$ ini bersifat hiperaktif. Menggunakan model Circuit Learning diharapkan dapat mengatasi masalah belajar siswa dan dapat membuat siswa menjadi termotivasi untuk mengikuti pelajaran yang disampaikan oleh guru serta dapat meningkatkan hasil belajar siswa, dengan pemilihan model pembelajaran yang sesuai dapat dijadikan cara baru untuk menarik perhatian peserta didik agar berhasil mencapai target dalam pembelajaran.

Model Circuit Learning memiliki beberapa kelebihan. Menurut Huda (2014:313) kelebihan penggunaan model Circuit Learning yaitu meningkatkan kreativitas siswa dalam merangkai kata dengan bahasa sendiri dan melatih konsentrasi siswa untuk fokus pada peta konsep yang diasajikan guru. Sejalan dengan pendapat tersebut, Siswanto (2016:59) menyatakan keunggulan model Circuit Learning yaitu kreativitas siswa dalam merangkai kata dengan bahasa sendiri lebih terasah dan konsentrasi yang terjadi membuat siswa fokus dalam belajar. Selama pembelajaran berlangsung siswa dapat mengamati, memperhatikan dan merangkai sendiri kalimat penjelas sehingga pemahaman materi akan lebih mendalam dan berkesan bagi siswa karena siswa ikut mengalami sendiri.

Model pembelajaran akan lebih sempurna apabila didukung dengan penggunaan media pembelajaran, salah satunya dengan memanfaatkan media pembelajaran. Media pembelajaran dapat dipahami sebagai "segala sesuatu yang dapat menyampaikan atau menyalurkan pesan dari suatu sumber secara terencana, sehingga terjadi lingkungan belajar yang kondusif dimana penerimanya dapat melakukan proses belajar secara efesien dan efektif". Salah satu media pembelajaran yang dapat digunakan yaitu media gambar. "Gambar yang dimaksudkan di sini termasuk foto, lukisan/ gambar, dan sketsa (gambar garis)" (Arsyad, 2015:109). Melalui penggunaan media gambar, guru dapat menyalurkan materi pembelajaran dengan lebih optimal sehingga dapat merangsang pikiran dan kemauan peserta didik untuk belajar. Kelebihan media gambar adalah sifatnya konkret, lebih realis menunjukan pada pokok masalah bila dibandingkan dengan verbal semata. Gambar dapat mengatasi ruang dan waktu, artinya tidak semua benda, obyek, peristiwa dapat dibawa ke kelas, dan pembelajar tidak dapat dibawa ke obyek tersebut. Maka perlu diciptakan dengan membuat gambar atau foto benda tersebut. Memperjelas suatu sajian masalah dalam bidang apa saja dan untuk tingkat usia berapa saja.

Berdasarkan latar belakang yang telah diuraian tersebut serta berbagai hasil penelitian sebelumnya membuat peneliti tertarik untuk melakukan penelitian dengan judul Pengaruh Model 
Circuit Learning Berbantuan Media Gambar Terhadap Kompetensi Pengetahuan PPKn Siswa Kelas V SD Gugus VI Kecamatan Mengwi Tahun Ajaran 2018/2019.

Tujuan yang ingin dicapai dalam penelitian ini adalah untuk mendeskripsikan kompetensi pengetahuan PPKn kelompok siswa yang dibelajarkan dengan model Circuit Learning berbantuan media gambar pada siswa kelas V SD Gugus VI Kecamatan Mengwi Tahun Ajaran 2018/2019, untuk mendeskripsikan kompetensi pengetahuan PPKn kelompok siswa yang dibelajarkan secara konvensional pada siswa kelas V SD Gugus VI Kecamatan Mengwi Tahun Ajaran 2018/2019, dan untuk mengetahui perbedaan signifikan kompetensi pengetahuan PPKn kelompok siswa yang dibelajarkan melalui model Circuit Learning berbantuan media gambar dengan kelompok siswa dibelajarkan secara konvensional pada siswa kelas V SD Gugus VI Kecamatan Mengwi Tahun Ajaran 2018/2019.

\section{Metode}

Penelitian ini dilaksanakan di SD Gugus VI Kecamatan Mengwi, Kabupaten Badung tahun ajaran 2018/2019. Waktu penelitian ini dilaksanakan mulai dari penyusunan proposal sampai dengan penyelesaian laporan yaitu pada bulan Desember 2018 sampai dengan bulan Mei 2019. Perlakuan diberikan sebanyak 6 kali di kelompok eksperimen dan 6 kali di kelompok kontrol. Jumlah perlakuan yang diberikan disesuaikan dengan jam pelajaran terkait materi dalam penelitian ini yang telah diatur dalam kurikulum dengan menyesuaikan jam pelajaran di sekolah.

Penelitian ini merupakan jenis penelitian kuantitatif dengan rancangan eksperimen semu (quasi experiment). Desain eksperimen yang digunakan dalam penelitian ini adalah Nonequivalent Kontrol Group Design. Dalam desain ini terdapat dua kelompok, yaitu kelompok eksperimen dan kelompok kontrol. "Dalam desain ini, subjek penelitian atau partisipan penelitian tidak dipilih secara acak untuk dilibatkan dalam kelompok eksperimen dan kelompok kontrol" (Setyosari, 2015:210). Berdasarkan hal tersebut, peneliti harus mengambil subjek penelitian sesuai dengan kelompok atau kelas yang ada sesuai kebijakan sekolah karena tidak memungkinkan untuk membuat kelompok atau kelas baru dalam suatu sekolah. Desain penelitian ini seperti pada gambar 1 berikut ini.

\begin{tabular}{|ccc|}
\hline $\mathrm{O}_{1}$ & $\mathrm{X}$ & $\mathrm{O}_{2}$ \\
\hline $\mathrm{O}_{3}$ & & $\mathrm{O}_{4}$ \\
\hline
\end{tabular}

Gambar 1. Desain Nonequivalent Kontrol Group Design

(Sumber: Sugiyono, 2014:116)

Keterangan:

$\mathrm{X}=$ perlakuan

$\mathrm{O}_{1} \quad=$ pretest kelompok eksperimen

$\mathrm{O}_{2} \quad=$ posttest kelompok eksperimen

$\mathrm{O}_{3} \quad=$ pretest kelompok kontrol

$\mathrm{O}_{4} \quad=$ posttest kelompok kontrol

Berdasarkan desain eksperimen semu dengan bentuk nonequivalent kontrol group design, dalam penelitian ini pre-test diberikan pada kelompok eksperimen dan kelompok kontrol sebagai penyetaraan kelompok. Setelah diberikan pretest peneliti memberikan perlakuan dalam pembelajaran, yaitu memberikan perlakuan dengan model Circuit Learning berbantuan media gambar kepada kelompok eksperimen sedangkan kelompok kontrol mendapat perlakuan dengan menggunakan pembelajaran konvensional. Kemudian setelah diberikan perlakuan, dilakukan posttest untuk mengetahui kompetensi pengetahuan PPKn. Pelaksanaan eksperimen dalam 
penelitian ini terdiri dari tiga tahapan yaitu, 1) tahap persiapan eksperimen, 2) tahap pelaksanaan eksperimen, dan (3) tahap akhir eksperimen.

Populasi dalam sebuah penelitian adalah kumpulan individu atau objek yang memiliki sifatsifat umum. Menurut Sugiyono (2018:80) populasi merupakan wilayah generalisasi yang terdiri atas objek/subjek yang mempunyai kualitas dan karakteristik tertentu yang ditetapkan oleh peneliti untuk dipelajari dan kemudian ditarik kesimpulannya. Populasi dalam penelitian ini adalah seluruh kelas V SD Gugus VI Kecamatan Mengwi, Tahun Ajaran 2018/2019 yang berjumlah 210 siswa. Berdasarkan hasil wawancara dengan Kepala Sekolah di Gugus Inti, diperoleh informasi bahwa kelas V SD di Gugus VI Kecamatan Mengwi homogen. Masing- masing individu tiap sekolah negeri pada Gugus VI Kecamatan Mengwi dianggap setara karena disebar secara merata antara siswa yang memiliki kemampuan tinggi, sedang dan rendah. Hal tersebut berarti tidak terdapat kelas unggulan maupun non unggulan.

Berdasarkan populasi yang telah ditentukan maka selanjutnya diambil perwakilan dari populasi tersebut yang mewakili seluruh populasi. Perwakilan dari populasi yang mewakili seluruh populasi disebut sampel. Menurut Agung (2014:69) sampel merupakan sebagian dari populasi yang diambil, yang dianggap mewakili seluruh populasi dan diambil dengan menggunakan teknik tertentu. Dalam penelitian ini sampel yang dipilih adalah dua kelas, yaitu satu kelas eksperimen dan satu kelas kontrol. Untuk pemilihan sampel penelitian ini tidak dilakukan pengacakan individu, karena tidak bisa mengubah kelas yang telah terbentuk sebelumnya. Kelas dipilih sebagaimana telah terbentuk tanpa campur tangan peneliti dengan tujuan untuk mencegah kemungkinan subjek mengetahui dirinya dilibatkan dalam penelitian sehingga penelitian ini benar-benar menggambarkan perlakuan yang diberikan.

Pengambilan sampel pada penelitian ini menggunakan teknik sampling untuk menentukan sampel yang akan digunakan. Teknik sampling yang digunakan dalam penelitian ini adalah Random Sampling. "Dalam teknik ini setiap individu memiliki peluang atau kesempatan yang sama untuk dijadikan subjek penelitian" (Setyosari, 2015:223). Untuk menentukan sampel, cara yang digunakan adalah dengan cara pengundian. Setelah dilakukan pengundian, diperoleh 2 kelas sampel yaitu kelas V SD No. 1 Kapal dan kelas V SD No. 4 Kapal. Kedua kelas sampel tersebut kemudian diberikan pretest dan hasil pretest dianalisis dengan uji-t untuk mengetahui kesetaraan kelompok. Sebelum dilakukan uji kesetaraan, data nilai pretest sampel diuji prasyarat terlebih dahulu, yaitu uji normalitas dengan teknik Kolmogorov-Smirnov dan homogenitas varians dengan Uji Fisher $(F)$.

Untuk melakukan metode pengumpulan data, diperlukan sebua alat yang digunakan. Alat tersebut diistilahkan dengan instrumen. "Instrumen penelitian adalah suatu alat yang digunakan mengukur fenomena alam maupun sosial yang diamati” (Sugiyono, 2018:102). Lebih lanjut Agung (2014:191) mengungkapkan "instrumen adalah alat yang digunakan untuk mengumpulkan data di lapangan sesuai dengan kebutuhan". Data yang dikumpulkan oleh peneliti nantinya akan dipergunakan untuk menguji hipotesis atau menjawab rumusan masalah, karena data tersebut dipergunakan untuk penarikan sebuah kesimpulan maka data yang dikumpulkan haruslah terbukti keaslian dan kebenarannya.

Metode pengumpulan data yang digunakan dalam penelitian ini adalah metode tes. Menurut Sudijono (2012:66) "test adalah alat atau prosedur yang dipergunakan dalam rangka pengukuran dan penilaian". Tes yang akan digunakan untuk mengukur kompetensi pengetahuan PPKn siswa berupa tes objektif dalam bentuk pilihan ganda biasa. Tes pilihan ganda biasa ini meliputi 4 pilihan jawaban (a, b, c atau d) dengan jumlah pertanyaan yaitu 50 butir soal. Menurut Agung (2013:71) menyatakan "penskoran tes objektif adalah 0 (nol) dan 1 (satu). Skor 1 diberikan untuk jawaban benar pada tiap butir tes/soal. Sedangkan 0 diberikan untuk jawaban salah pada tiap butir tes/soal". Sebelum memberikan soal kepada kelompok eksperimen dan kelompok kontrol, soal terlebih dahulu diuji coba. Selanjutnya dilakukan pengujian validitas, uji daya beda, indeks kesukaran, dan uji reliabilitas. Uji coba bertujuan untuk mendapatkan gambaran apakah instrumen berupa tes pilihan ganda biasa kompetensi pengetahuan PPKn 
tersebut layak digunakan sebagai instrumen penelitian yang baik. Tes pilihan ganda biasa yang digunakan dalam penelitian ini disesuaikan dengan indikator yang terdapat dalam tema.

Pada penelitian ini menggunakan 2 variabel, variabel terikat (dependent) dan varibel bebas (independent). Variabel bebas merupakan variabel yang mempengaruhi atau yang menjadi sebab perubahannya atau timbulnya variabel terikat. Variabel terikat merupakan variabel yang dipengaruhi atau yang menjadi akibat, karena adanya variabel bebas. Variabel bebas dalam penelitian ini adalah Model Circuit Learning berbantuan media gambar, sedangkan variabel terikat adalah kompetensi pengetahuan PPKn.

Teknik analisis yang digunakan untuk menganalisis data dalam penelitian ini adalah teknik analisis statistik deskriptif dan statistik inferensial. Statistik deskriptif digunakan untuk menganalisis data posttest kompetensi pengetahuan PPKn siswa kelompok eksperimen dan kelompok kontrol. Sedangkan statistik inferensial digunakan untuk menganalisis data gain skor yang ternormalisasi dari hasil pretest dan posttest. Teknik analisis statistik deskriptif dalam penelitian ini digunakan untuk mendeskripsikan data kompetensi pengetahuan PPKn siswa yang dibelajarkan dengan model Circuit Learning berbantuan media gambar dan kompetensi pengetahuan PPKn siswa yang dibelajarkan dengan pembelajaran konvensional dengan menggunakan pendekatan saintifik. Statistik deskriptif yang digunakan yaitu mean, standar deviasi, varians. "Analisis statistik inferensial ialah suatu cara pengolahan data yang dilakukan dengan jalan menerapkan rumus-rumus statistik inferensial untuk menguji suatu hipotesis penelitian yang diajukan peneliti dan kesimpulan ditarik berdasarkan pengujian terhadap hipotesis" (Agung, 2014:110). Sebelum dilaksanakan pengujian hipotesis terlebih dahulu dilakukan uji prasyarat analisis dengan uji normalitas dan uji homogenitas. Setelah data dianalisis dengan uji normalitas dan homogenitas, maka data berdistribusi normal dan varians homogen, selanjutnya analisis data akan dilanjutkan untuk menguji hipotesis dengan uji-t ( $t$-test) dengan rumus polled varians. Dengan kriteria pengujian jika harga $t_{\text {hitung }} \leq t_{\text {tabel, }}$, maka $\mathrm{H}_{\mathrm{o}}$ diterima, dan jika harga $t_{\text {hitung }}>t_{\text {tabel }}$ maka $H_{o}$ ditolak. Pada taraf signifikan $5 \%$ dengan $d k=n_{1}+n_{2}-2$.

\section{Hasil dan Pembahasan}

Penelitian ini merupakan jenis penelitian quasi experiment atau eksperimen semu menggunakan rancangan nonequivalent control group design yang dianalisis menggunakan uji-t. Objek yang diteliti adalah kompetensi pengetahuan PPKn siswa kelas V dari penggunaan model Circuit Learning berbantuan media gambar dan model pembelajaran konvensional. Dengan demikian data pada penelitian ini diklasifikasikan menjadi dua yaitu, (1) kompetensi pengetahuan PPKn siswa kelas V yang dibelajarkan dengan model Circuit Learning berbantuan media gambar (kelompok eksperimen), (2) kompetensi pengetahuan PPKn siswa kelas V yang dibelajarkan dengan pembelajaran konvensional (kelompok kontrol). Sebelum diberikan perlakuan sebanyak 6 kali penerapan RPP, siswa diberikan pre-test dan di akhir eksperimen siswa diberikan posttest untuk memperoleh data kompetensi pengetahuan PPKn siswa. Data Pre-test dan posttes kemudian diolah menjadi data gain skor yang ternormalisasi. Berdasarkan hasil analisis statistik deskriptif kompetensi pengetahuan PPKn kelas eksperimen diperoleh rata-rata (mean) $=0,666$ dan standar deviasi $(S D)=0,178$. Dikonversikan pada tabel PAN skala lima, sehingga dapat diketahui kompetensi pengetahuan PPKn siswa kelas eksperimen berada pada kategori cukup (C). Hasil analisis statistik deskriptif kompetensi pengetahuan PPKn kelas kontrol diperoleh nilai rata-rata (mean) $=0,534$ dan standar deviasi $(S D)=0,140$. Dikonversikan pada tabel PAN skala lima, sehingga dapat diketahui kompetensi pengetahuan PPKn siswa kelas kontrol berada pada katagori cukup (C). Hasil rentangan yang diperoleh dari setiap kelompok kelas berbeda sehingga hasil tersebut dapat digunakan pada kelas yang bersangkutan dan tidak boleh digunakan pada kelas lainnya. Rekapitulasi hasil deskripsi data kompetensi pengetahuan PPKn kelas eksperimen dan kelas kontrol disajikan pada tabel 1. sebagai berikut.

Tabel 1.

Hasil Deskripsi Data Kompetensi Pengetahuan PPKn Kelas Eksperimen dan Kelas Kontrol

No Data Statistik

Kelas Eksperimen

Kelas Kontrol 


\begin{tabular}{llll}
\hline 1 & Nilai Rata-rata (Mean) & 0,666 & 0,534 \\
\hline 2 & Standar Deviasi & 0,178 & 0,140 \\
\hline 3 & Varians & 0,032 & 0,020 \\
\hline 4 & Nilai Maksimum & 0,947 & 0,765 \\
\hline 5 & Nilai Minimum & 0,200 & 0,200 \\
\hline
\end{tabular}

Berdasarkan hasil perhitungan analisis deskripsi data kompetensi pengetahuan PPKn menunjukkan bahwa kompetensi pengetahuan PPKn kelas eksperimen, yaitu kelompok siswa yang dibelajarkan dengan menggunakan model Circuit Learning berbantuan media gambar memiliki nilai rata-rata lebih tinggi dari pada kelas kontrol, yaitu kelompok siswa yang dibelajarkan secara konvensional.

Sebelum dilakukan pengujian hipotesis dengan analisis uji-t, terlebih dahulu harus dilakukan uji prasyarat yang meliputi uji normalitas sebaran data dengan teknik kolmogorov smirnov dan uji homogenitas varians dengan uji fisher. Uji prasyarat pada penelitian ini dilakukan setelah diperoleh data gain skor yang ternormalisasi di kedua kelompok yaitu kelompok eksperimen dan kelompok kontrol. Uji normalitas sebaran data kelompok eksperimen diperoleh nilai maksimum yaitu 0,087 . Nilai tersebut digunakan sebagai angkan penguji normalitas sebaran data pada taraf signifikan $5 \%$ untuk $\mathrm{n}=31$ diperoleh nilai tabel kolmogorov-smirnov yaitu 0,238 sehingga perbandingan nilai maksimum < nilai tabel kolmogorov-smirnov yaitu 0,087 <0,238, maka $\mathrm{H}_{0}$ diterima dan sebaran data gain skor ternormalisas kompetensi pengetahuan PPKn sebaran data kelompok kelas eksperimen berdistribusi normal. Berdasarkan hasil penghitungan tabel kerja uji normalitas sebaran data kelompok kontrol diperoleh nilai maksimum yaitu 0,074. Nilai tersebut digunakan sebagai angkan penguji normalitas sebaran data pada taraf signifikan $5 \%$ untuk $\mathrm{n}=39$ diperoleh nilai tabel kolmogorov-smirnov yaitu 0,213 sehingga perbandingan nilai maksimum < nilai tabel kolmogorov-smirnov yaitu 0,074<0,213, maka $\mathrm{H}_{0}$ diterima dan sebaran data gain skor ternormalisas kompetensi pengetahuan PPKn sebaran data kelompok kelas kontrol berdistribusi normal.

Uji homogenitas varians dilakukan terhadap data gain skor ternormalisasi kompetensi pengetahuan PPKn kelompok kelas eksperimen dan kelompok kelas kontrol. Dari hasil analisis diketahui varians data kompetensi pengetahuan PPKn siswa kelompok eksperimen adalah 0,032 dan kelompok kontrol adalah 0,020. Uji homogenitas varians yang dilakukan dalam penelitian ini menggunakan uji F. Rekapitulasi hasil uji homogenitas varians dari data gain skor ternormalisasi kompetensi pengetahuan PPKn sampel penelitian disajikan pada tabel 2 sebagai berikut.

Tabel 2.

Rekapitulasi Hasil Uji Homogenitas Varians dari Data Gain skor Ternormalisasi Kompetensi Pengetahuan PPKn

\begin{tabular}{|c|c|c|c|c|c|c|}
\hline No & Sampel & Varians & $\mathrm{dk}$ & $F_{\text {hitung }}$ & $\mathrm{F}_{\text {tabel }}$ & Simpulan \\
\hline 1 & Kelas Eksperimen & 0,032 & 30 & \multirow{2}{*}{1,60} & \multirow{2}{*}{1,76} & \multirow{2}{*}{ Homogen } \\
\hline 2 & Kelas Kontrol & 0,020 & 38 & & & \\
\hline
\end{tabular}

Dari hasil perhitungan diperoleh $\mathrm{F}_{\text {hitung }}=1,60$, ini kemudian dibandingkan dengan harga $\mathrm{F}_{\text {tabel }}$ pada taraf signifikansi $5 \%(\alpha=0,05)$ dengan dk untuk pembilang $(31-1=30)$ dan dk untuk penyebut (39-1 = 38), sehingga diperoleh $\mathrm{F}_{\text {tabel }}=1,76$. Hal ini berarti $\mathrm{F}_{\text {hitung }}<\mathrm{F}_{\text {tabel, }}$ maka $\mathrm{H}_{0}$ diterima dan data gain skor ternormalisas kompetensi pengetahuan PPKn sampel penelitian dinyatakan memiliki varians yang homogen. Berdasarkan hasil uji prasyarat analisis yang meliputi uji normalitas sebaran data dan uji homogenitas varians, disimpulkan bahwa data kedua kelompok sampel penelitian ialah berdistribusi normal dan memiliki varians yang homogen. Sesuai dengan hasil tersebut dapat dilakukan pengujian hipotesis mempergunakan statistik 
parametrik dengan uji-t. Rekapitulasi Hasil uji-t dari Data Gain skor Ternormalisasi Kompetensi Pengetahuan PPKn Sampel Penelitian disajikan pada tabel 3. sebagai berikut.

Tabel 3.

Rekapitulasi Hasil uji-t dari Data Gain skor Ternormalisasi Kompetensi Pengetahuan PPKn Sampel Penelitian

\begin{tabular}{cccccccc}
\hline No & \multicolumn{1}{c}{ Sampel } & $\mathrm{N}$ & $\overline{\mathrm{x}}$ & $\mathrm{S}^{2}$ & $\mathrm{t}_{\text {hitung }}$ & $\mathrm{t}_{\text {tabel }}$ & Simpulan \\
\hline \multirow{2}{*}{1} & $\begin{array}{l}\text { Kelas } \\
\text { Eksperimen }\end{array}$ & 31 & 0,666 & 0,032 & & & \\
\cline { 1 - 6 } 2 & Kelas Kontrol & 39 & 0,534 & 0,020 & & 2,000 & $\mathrm{H}_{0}$ ditolak \\
\hline
\end{tabular}

Dari hasil analisis diperoleh $t_{\text {hitung }}$ sebesar 3,474, kemudian dibandingkan dengan $t_{\text {tabel }}$ pada taraf signifikansi $5 \%(\alpha=0,05)$ dengan $\mathrm{dk}(31+39-2=68)$, sehingga diperoleh $t_{\text {tabel }}$ sebesar 2,000 . Karena $t_{\text {hitung }}>t_{\text {tabel }}(3,474>2,000)$ maka $\mathrm{H}_{0}$ yang berbunyi tidak terdapat perbedaan yang signifikan kompetensi pengetahuan PPKn antara kelompok siswa yang dibelajarkan dengan model Circuit Learning berbantuan media gambar dengan kelompok siswa yang dibelajarkan dengan pembelajaran konvensional pada siswa kelas V SD Gugus VI Kecamatan Mengwi Tahun Ajaran 2018/2019 ditolak dan $\mathrm{H}_{\mathrm{a}}$ yang berbunyi terdapat perbedaan yang signifikan kompetensi pengetahuan PPKn antara kelompok siswa yang dibelajarkan dengan model Circuit Learning berbantuan media gambar dengan kelompok siswa yang dibelajarkan dengan pembelajaran konvensional pada siswa kelas V SD Gugus VI Kecamatan Mengwi Tahun Ajaran 2018/2019 diterima. Dengan demikian, model Circuit Learning berbantuan media gambar berpengaruh terhadap kompetensi pengetahuan PPKn siswa kelas V SD Gugus VI Kecamatan Mengwi tahun ajaran 2018/2019.

Hasil uji hipotesis yang telah diperoleh menunjukkan $t_{\text {hitung }}=3,474$, pada taraf signifikansi $5 \%$ dengan $\mathrm{dk}=68$ diperoleh tabel sebesar 2,000. Berdasarkan hasil analisis yang diperoleh bahwa terdapat perbedaan model Circuit Learning berbantuan media gambar terhadap kompetensi pengetahuan PPKn siswa kelas V SD Gugus VI Kecamatan Mengwi tahun ajaran 2018/2019.

Perbedaan signifikan kompetensi pengetahuan PPKn antara kelompok siswa yang dibelajarkan dengan model Circuit Learning berbantuan media gambar dengan kelompok siswa dibelajarkan dengan pembelajaran konvensional dapat dilihat dari perbedaan hasil analisis statistik deskriptif kedua kelompok tersebut. Secara deskriptif rata-rata gain skor ternormalisasi kompetensi pengetahuan PPKn siswa kelompok eksperimen $\bar{X}=0,666$ lebih dari rata-rata gain skor ternormalisasi kompetensi pengetahuan PPKn kelompok kontrol $\bar{X}=0,534$. Berdasarkan hasil temuan tersebut, dapat dinyatakan bahwa kedua kelompok sampel penelitian awalnya memiliki kemampuan setara, setelah diberikan perlakuan berupa pembelajaran dengan menggunakan model Circuit Learning berbantuan media gambar pada kelompok eksperimen dan pembelajaran menggunakan pendekatan saintifik pada kelompok kontrol diperoleh hasil kompetensi pengetahuan PPKn yang berbeda.

Perbedaan rata-rata kompetensi pengetahuan PPKn siswa pada kelompok eksperimen dan kelompok kontrol tersebut disebabkan karena pembelajaran dengan menerapkan model Circuit Learning pada kelompok eksperimen memberikan kesempatan yang lebih banyak kepada siswa untuk mengkonstruksi atau membentuk pemahamannya sendiri terhadap konsep pelajaran dengan membuat peta konsep sendiri mengenai pembelajaran yang telah dipelajari. Dalam pembuatan peta konsep, kolaborasi antara pemahaman (pengetahuan) dan keterampilan siswa memiliki porsi yang relatif berimbang sehingga penerapan model Circuit Learning berbantuan media gambar tidak hanya dapat dirasakan oleh siswa yang pandai dalam segi kognitif saja tetapi juga siswa yang lemah dalam segi kognitif tetapi memiliki keterampilan untuk membuat peta konsep. Dengan pola pembelajaran penambahan dan pengulangan akan mempermudah siswa dalam memahami pembelajaran. Pembelajaran kelompok kelas kontrol dalam menyampaikan materi kepada siswa hanya diselingi dengan sedikit tanya jawab kemudian diikuti dengan pemberian tugas secara individu. Dengan pembelajaran seperti ini, siswa belum 
optimal mempunyai kesempatan untuk mengembangkan kemampuan berpikir, kesempatan untuk mengajukan ide yang dimiliki, serta memecahkan masalah yang ditemui. Pembelajaran seperti ini, membuat siswa merasa bosan dan jenuh sehingga sulit untuk memahami materi pelajaran. Dengan demikian, perbedaan hasil kompetensi pengetahuan PPKn siswa dapat terlihat dari keunggulan penerapan model Circuit Learning berbantuan media gambar, nilai rata-rata gain skor ternormalisasi, dan hasil uji hipotesis dari kelompok kelas eksperimen dan kelompok kelas kontrol.

Hasil penelitian ini memiliki persamaan dengan penelitian sebelumnya yang relevan dan mendukung hasil penelitian relevan. Penelitian ini mendukung hasil penelitian yang dilakukan oleh Dewi (2014) dengan judul "Pengaruh Model Pembelajaran Circuit Learning Berbantuan Media Audiovisual Terhadap Hasil Belajar IPS Siswa Kelas V SD Negeri 1 Pejeng". Selain itu penelitian ini juga mendukung penelitian oleh Febria (2018) yang menyatakan bahwa model pembelajaran Circuit Learning berpengaruh terhadap hasil belajar IPS siswa kelas III SDN 56. Dengan demikian, dapat dinyatakan bahwa model Circuit Learning berbantuan media gambar berpengaruh terhadap kompetensi pengetahuan PPKn siswa kelas V SD Gugus VI Kecamatan Mengwi Tahun Ajaran 2018/2019.

\section{Simpulan dan Saran}

Berdasarkan hasil analisis data kompetensi pengetahuan PPKn pada kelompok siswa yang dibelajarkan dengan model Circuit Learning berbantuan media gambar pada siswa kelas V SD Gugus VI Kecamatan Mengwi Tahun Ajaran 2018/2019, diperoleh nilai rata-rata $=0,666$ dengan standar deviasi $=0,178$ dan varians $=0,032$. Selain itu nilai maksimum pada kelompok eksperimen adalah 0,947 dan nilai minimun adalah 0,200. Dikonversikan pada tabel PAN skala lima, sehingga dapat diketahui kompetensi pengetahuan PPKn siswa kelas eksperimen berada pada katagori cukup (C). Sedangkan berdasarkan hasil analisis data kompetensi pengetahuan PPKn kelompok siswa yang dibelajarkan melalui pembelajaran konvensional di kelas V SD Gugus VI Kecamatan Mengwi tahun ajaran 2018/2019, diperoleh nilai rata-rata = 0,534 dengan standar deviasi $=0,140$ dan varians $=0,020$. Selain itu nilai maksimum pada kelompok kontrol adalah 0,765 dan nilai minimun adalah 0,200. Dikonversikan pada tabel PAN skala lima, sehingga dapat diketahui kompetensi pengetahuan PPKn siswa kelas kontrol berada pada katagori cukup (C).

Berdasarkan hasil analisis uji-t kompetensi pengetahuan PPKn kelompok siswa yang dibelajarkan melalui model circuit learning dengan kelompok siswa yang dibelajarkan secara konvensional di kelas V SD Gugus VI Kecamatan Mengwi tahun ajaran 2018/2019, diperoleh harga $t_{\text {hitung }}=3,474>$ harga $t_{\text {tabel }}=2,000$, maka $\mathrm{H}_{0}$ ditolak dan hipotesis alternatif (Ha) yang menyatakan terdapat perbedaan yang signifikan kompetensi pengetahuan PPKn antara kelompok siswa yang dibelajarkan melalui model circuit learning berbantuan media gambar dengan kelompok siswa dibelajarkan secara konvensional pada kelas V SD Gugus VI Kecamatan Mengwi Tahun Ajaran 2018/2019 diterima. Dari hasil analisis tersebut dapat disimpulkan bahwa model circuit learning berbantuan media gambar berpengaruh terhadap kompetensi pengetahuan PPKn siswa kelas V SD Gugus VI Kecamatan Mengwi Tahun Ajaran 2018/2019.

Berdasarkan hasil penelitian, maka saran yang dapat diajukan kepada pihak-pihak sebagai berikut. (1) Kepada Guru, Berdasarkan temuan penelitian yang diperoleh, disarankan kepada guru agar lebih kreatif untuk memberikan variasi dalam pembelajaran, sumber belajar dan kesempatan yang lebih besar bagi siswa pada pembelajaran dengan menggunakan model Circuit Learning berbantuan media gambar sehingga tercipta pembelajaran bermakna dan menyenangkan bagi siswa. (2) Kepada Kepala Sekolah, Kepala sekolah hendaknya memfasilitasi terlaksananya model Circuit Learning berbantuan media gambar untuk 
menunjang pembelajaran agar siswa semakin termotivasi untuk belajar dan memanfaatkan fasilitas tersebut untuk mengoptimalkan hasil belajar siswa sehingga mutu sekolah menjadi meningkat. (3) Kepada peneliti lain, Kepada penelitian lain dapat melakukan penelitian lebih lanjut mengenai pengaruh model circuit learning berbantuan media gambar pada muatan materi pembelajaran yang berbeda dan pada sampel yang berbeda sehingga hasil penelitian ini benarbenar dapat menggambarkan keadaan sesungguhnya yang terjadi di lapangan.

\section{Daftar Pustaka}

Agung. A.A. Gede. 2014. Buku Ajar Metodologi Penelitian Pendidikan. Malang: Aditya Media Publishing.

Arsyad, Azhar. 2015. Media Pembelajaran. Jakarta: Rajawali Press.

Dewi, Dewa Ayu Puspa. 2014. Pengaruh Model Pembelajaran Circuit Learning Berbantuan Media Audiovisual Terhadap Hasil Belajar IPS Siswa Kelas V. Jurnal Mimbar PGSD Universitas Pendidikan Ganesha.

Hamalik, Oemar. 2017. Kurikulum dan Pembelajaran. Jakarta: Bumi Aksara.

Hardianti. 2018. Pengaruh Model Pembelajaran Make a Match Berbantuan Media Gambar Terhadap Hasil Belajar PKn Pada Materi Organisasi di Lingkungan Masyarakat. Jurnal Keilmuan dan Kependidikan Dasar p-ISSN, vol. 10, No. 1.

Huda, Miftahul. 2014. Model-Model Pengajaran Dan Pembelajaran. Yogyakarta: Pustaka Pelajar.

Permendikbud Nomor 24 Tahun 2016 tentang Kompetensi Inti dan Kompetensi Dasar Pelajaran Dalam Kurikulum 2013 Pada Pendidikan Dasar dan Pendidikan Menengah, 2016. Jakarta: Departemen Pendidikan dan Kebudayaan.

Rusman. 2017. Belajar dan Pembelajaran Berorientasi Standar Proses Pendidikan. Jakarta: Kencana.

Sanaky, Hujair AH. 2009. Media Pembelajaran. Yogyakarta: Safiria Insania Press.

Setyosari, H. Punaji. 2015. Metode Penelitian Pendidikan. Jakarta: Prenadamedia Group.

Shoimin, Aris. 2014. 68 Model Pembelajaran Inovatif dalam Kurikulum 2013. Yogyakarta: ArRuzz Media. 
Siswanto, Wahyudi. 2016. Model Pembelajaran Menulis Cerita Buku Panduan untuk Guru Ketika Mengajar Menulis Cerita. Bandung: PT Refika Aditama.

Sugiyono. 2014. Metode Penelitian Pendidikan Pendekatan Kuantitatif, Kualitatif dan R\&D. Bandung: Alfabeta.

Sugiyono. 2018. Metode Penelitian Pendidikan Pendekatan Kuantitatif, Kualitatif dan R\&D. Bandung: Alfabeta.

Susanto, Ahmad. 2013. Teori Belajar \& Pembelajaran di Sekolah Dasar. Jakarta: Prenada Media Group.

Undang-undang Nomor 20 Tahun 2003 tentang Sistem Pendidikan Nasional, 2003. Jakarta: Departemen Pendidikan Nasional.

\footnotetext{
* Corresponding author.

e-mail: : putu.sinta.fitriani@undiksha.ac.id¹ ,igaagungsri.asri@undiksha.ac.id², igustiagungoka.negara@undiksha.ac.id³
} 